\title{
IMPLEMENTASI KEBIJAKAN PEMERINTAH KABUPATEN PONOGORO DALAM PENETAPAN STATUS KEJADIAN LUAR BIASA (KLB) WABAH DEMAM BERDARAH DENGUE (DBD) DI KABUPATEN PONOROGO
}

\author{
Khoirul Anisak $^{(1)}$, Dian Suluh Kusuma Dewi ${ }^{(2)}$ \\ Program Studi Ilmu Pemerintahan, Fakultas Ilmu Sosial dan Ilmu Politik \\ Universitas Muhammadiyah Ponorogo Jl. Budi Utomo Nomor 10, Ronowijayan, Kecamatan Siman, Kabupaten \\ Ponorogo, 163471, Jawa Timur, Indonesia
}

Email: khoirulanisak@gmail.com ${ }^{(1)}$,suluh.dian@gmail.com ${ }^{(2)}$

\begin{abstract}
ABSTRAK
Penyakit Demam Berdarah Dengue (DBD) merupakan salah satu permasalahan kesehatan masyarakat yang terjadi di Indonesia dengan jumlah penderita yang terus meningkat dan penyebaran yang semakin luas sejalan dengan meningkatnya mobilitas dan kepadatan penduduk. Penyakit Demam Berdarah Dengue (DBD) merupakan penyakit menular yang disebabkan oleh virus dengue dan disebarkan oleh nyamuk terutama spesies nyamuk Aedes Aegypti. Pada tahun 2016 ini penyakit Demam Berdarah Dengue (DBD) masih menjadi masalah di Kabupaten Ponorogo. Selain sangat berpotensi menimbulkan Kejadian Luar Biasa (KLB), Selama Sembilan tahun terakhir menjadikan Kabupaten Ponorogo sebagai Kabupaten Endemis. Menurut data rekapitulasi Dinas Kesehatan tentang kasus DBD di Ponorogo pada tahun 2019, terdapat 17 Kecamatan terserang DBD, dengan total penderita sebanyak 973 orang dan kematian 9 orang. Tingginya angka kesakitan DBD disebabkan karena adanya iklim yang tidak stabil dan curah hujan cukup banyak pada musim penghujan yang merupakan sarana perkembangbiakan nyamuk Aedes aegypti yang cukup potensial. Selain itu juga didukung dengan tidak maksimal nya kegiatan Pemberantasan Sarang Nyamuk (PSN) di masyarakat sehingga menimbulkan Kejadian Luar Biasa (KLB). Permasalahan mengenai bagaimana implementasi kebijakan Pemerintah Kabupaten Ponorogo dalam penetapan status Kejadian Luar Biasa (KLB) wabah Demam Berdarah Dengue (DBD). Penelitian implementasi kebijakan Pemerintah Kabupaten Ponorogo dalam penetapan status Kejadian Luar Biasa (KLB) wabah Demam Berdarah Dengue (DBD) di Kabupaten Ponorogo menggunakan metode penelitian kualitatif deskriptif dengan teknik purposive sampling. Implementasi kebijakan dalam penetapan KLB DBD sejauh ini bisa dikatakan berjalan dengan baik hal ini dapat dilihat dari pelaksanaan di lapangan dan petugas yang selalu siaga dengan adanya kasus tersebut.
\end{abstract}

Kata kunci: Implementasi Kebijakan, Kejadian Luar Biasa (KLB), Demam Berdarah Dengue (DBD)

\section{ABSTRACT}

Dengue Hemorrhagic Fever (DHF) is one of the public health problems that occurs in Indonesia with the number of sufferers that continues to increase and the wider spread in line with increasing mobility and population density. Dengue Hemorrhagic Fever (DHF) is an infectious disease caused by dengue virus and spread by mosquitoes, especially the Aedes Aegypti mosquito species. In 2016 Dengue Hemorrhagic Fever $(D H F)$ is still a problem in Ponorogo Regency. Besides having the potential to cause Extraordinary Events (KLB), for the past nine years, Ponorogo Regency has become an Endemic District. According to data from the recapitulation of dengue cases in the Department of Health The high number of dengue cases in Ponorogo in 2019 were 17 sub-districts affected by dengue, with a total of 973 patients and 9 deaths. The high number of dengue fever is caused by an unstable climate and quite a lot of rainfall in the rainy season which is a potential breeding facility for Aedes aegypti mosquitoes. Besides that, it is also supported by the non-maximum activities in eradicating mosquito nests (PSN) in the community, causing an Extraordinary Event (KLB). Issues regarding how the implementation of the Ponorogo Regency government policy in determining the status of Extraordinary Events (KLB) outbreaks of Dengue Hemorrhagic Fever $(D H F)$. Research on the implementation of the Ponorogo district government policy in determining the status of Extraordinary Events $(K L B)$ outbreaks of Dengue Hemorrhagic Fever $(D H F)$ in Ponorogo Regency using descriptive qualitative research methods with purposive sampling technique. The implementation of the policy in determining the DBD KLB so far can be said to be going well, this can be seen from the implementation in the field and the officers who are always on alert with the case.

Keywords: Policy Implementation, Extraordinary Events (KLB), Dengue Hemorrhagic Fever (DHF) 


\section{PENDAHULUAN}

\section{A. Latar Belakang}

Undang-Undang Nomor 36 Tahun 2009 tentang Kesehatan tercantum pada pasal 9 ayat 1 dan 2 yaitu (1) setiap orang berkewajiban ikut mewujudkan, mempertahankan, dan meningkatkan derajat kesehatan masyarakat yang setinggitingginya, (2) kewajiban sebagaimana dimaksud pada ayat (1), pelaksanaannya meliputi upaya kesehatan perseorangan, upaya kesehatan masyarakat, dan pembangunan berwawasan kesehatan (UU No. 36 Tahun 2009). Di antara faktor-faktor yang mempengaruhi peningkatan tingkat kesehatan masyarakat adalah pertumbuhan populasi yang terus meningkat, perkembangan teknologi, dan kebutuhan hidup manusia yang semakin beragam, sementara sumber daya yang tersedia semakin terbatas. dan menyebabkan penurunan kualitas lingkungan dan masalah kesehatan manusia. (Novalia, 2016)

Demam berdarah dengue (DBD) adalah salah satu masalah kesehatan masyarakat di Indonesia. Jumlah pasien yang menderita itu terus meningkat dan luasnya bertambah seiring dengan peningkatan mobilitas dan kepadatan populasi. Demam berdarah dengue (DBD) adalah penyakit menular yang disebabkan oleh virus demam berdarah dan ditularkan oleh nyamuk, terutama spesies nyamuk Aedes Aegypti. Nyamuk yang menularkan demam berdarah hampir ada di seluruh wilayah Indonesia, kecuali di tempat yang tingginya lebih dari 1000 meter. Demam berdarah dengue ditemukan di hampir semua bagian dunia, terutama di negara tropis dan subtropis, baik sebagai penyakit endemik maupun epidemi. Demam berdarah dengue (DBD) adalah penyakit yang berkembang pesat yang dapat menyebabkan kematian dalam waktu singkat dan sering menyebabkan kejadian luar biasa (KLB).

World Health Organization (WHO) mencatat bahwa antara tahun 1968 dan 2009, Indonesia adalah salah satu negara dengan jumlah kasus demam berdarah tertinggi di Asia Tenggara. Berdasarkan profil kesehatan Indonesia, jumlah kasus antara 2014 dan 2015 meningkat dari 100.347 pada tahun 2014 menjadi 129.650 pada tahun 2015. Tujuan dari rencana strategis tingkat frekuensi DBD 2015 yang ditetapkan oleh Kementerian Kesehatan adalah 49\%, sehingga Indonesia tidak mencapai tujuan Rencana Strategis 2015. (Rahayu \& Budi, 2017).

Tingkat kejadian (rate insidence) atau demam berdarah dengue (DBD) di Jawa Timur pada tahun 2016 adalah 64,8 per 100.000 penduduk, meningkat dari tahun 2015 sebesar 54,18 per 100.000 penduduk. Angka ini masih lebih tinggi dari target nasional $\leq 49$ per 100.000 penduduk. Dilihat dari tingkat nyeri demam berdarah dengue (DBD) pada tahun 2016, di beberapa kabupaten / kota, jumlah orang yang menderita demam berdarah telah meningkat dibandingkan dengan masa lalu. Angka kematian akibat DBD atau tingkat fatalitas kasus (CFR) pada tahun 2017 adalah $1,3 \%$, menunjukkan bahwa tingkat kematian DHF di Jawa Timur masih melebihi target $<1 \%$. (Profil Kesehatan Jawa Timur, 2017).

Pada tahun 2016 ini penyakit Demam Berdarah Dengue (DBD) masih menjadi masalah di Kabupaten Ponorogo. Selain sangat berpotensi menimbulkan Kejadian Luar Biasa (KLB), Selama Sembilan tahun terakhir menjadikan Kabupaten Ponorogo sebagai Kabupaten Endemis. Suatu wilayah disebut endemis apabila selama 3 tahun berturut-turut selalu ditemukan adanya penderita DBD. Terjadi peningkatan kasus DBD di tahun 2016 sebanyak 891 kasus jika dibandingkan dengan tahun 2015 yang menemukan penderita sebanyak 773 penderita. Demikian juga dengan kematian akibat DBD juga mengalami peningkatan di tahun 2016 yaitu sebanyak 10 kasus. (Profil Kesehatan Kabupaten Ponorogo, 2016)

Menurut data rekapitulasi kasus DBD Dinas Kesehatan Tingginya kasus DBD di Ponorogo pada tahun 2019 terdapat 17 Kecamatan terserang DBD, dengan total penderita sebanyak 973 orang dan kematian 9 orang. Tingginya angka kesakitan DBD disebabkan karena adanya iklim yang tidak stabil dan curah hujan cukup banyak pada musim penghujan yang merupakan sarana perkembangbiakan nyamuk Aedes aegypti yang cukup potensial. Selain itu juga didukung dengan tidak maksimal nya kegiatan Pemberantasan Sarang Nyamuk (PSN) di masyarakat sehingga menimbulkan Kejadian Luar Biasa (KLB).

Keluarnya keputusan Bupati Ponorogo dengan SK No 188.45/1070/405.10/2019 tentang penetapan kejadian luar biasa (KLB) yang mana sudah memenuhi kriteria bahwa Ponorogo terkena DBD dengan jumlah pasien lebih dari tahun sebelumnya yaitu meningkat drastis atau dua kali lipat dibandingkan tahun sebelumnya dan menindaklanjutinya Bupati Ponorogo menetapkan bahwa kejadian ini menjadi Kejadian Luar Biasa (KLB) wabah Demam Berdarah Dengue (DBD) di Kabupaten Ponorogo.

Penetapan status Kejadian Luar Biasa (KLB) wabah Demam Berdarah Dengue (DBD) karena peningkatan jumlah kasus yang sangat signifikan. akan ada gerakan yang lebih kuat lagi untuk mengatasi keadaan, dengan semua dukungan pembiayaan. Adapun upaya-upaya yang dilakukan pemerintah Kabupaten Ponorogo salah satunya adalah Pemberantasan Sarang Nyamuk (PSN) dan Fogging agar nyamuk tidak berkembang biak dan menambah penderita DBD di Ponorogo. Selain itu Bupati Ponorogo meminta rumah sakit atau puskesmas untuk menggratiskan pasien DBD yang sedang menjalani opname melalui bantuan dari Dinas Kesehatan. 
Berdasarkan uraian diatas, maka penulis dalam hal ini tertarik untuk melakukan penelitian dengan mengangkat judul Implementasi Kebijakan Pemerintah Kabupaten Ponorogo Dalam Penetapan Status Kejadian Luar Biasa (KLB) Wabah Demam Berdarah Dengue (DBD) Tahun 2019 Di Dinas Kesehatan Kabupaten Ponorogo.

\section{STUDI KEPUSTAKAAN}

\section{A. Implementasi Kebijakan Publik}

Implementasi adalah upaya melaksanakan keputusan kebijakan (Nugroho, 2004:119). "Suatu program dinyatakan berlaku atau dirumuskan merupakan fokus perhatian implementasi kebijakan, yakni kejadian-kejadian dan kegiatankegiatan yang timbul sesudah disahkannya pedoman-pedoman kebijaksanaan negara, yang mencakup baik usaha-usaha untuk mengadministrasikannya maupun untuk menimbulkan akibat/dampak nyata pada masyarakat atau kejadian-kejadian”. Menurut Dunn (1999:103), proses implementasi kebijakan merupakan "hal yang lebih penting dari seluruh rangkaian proses kebijakan. Hal ini karena tingkat keberhasilan suatu kebijakan akan ditentukan oleh kemampuan mengimplementasikannya, meski dalam prosesnya terdapat berbagai masalah yang kompleks bahkan tidak jarang bermuatan politis dan intervensi dari berbagai kepentingan". (Massi, 2011).

Implementasi kebijakan dipandang dalam pengertian yang luas, merupakan "tahap dari proses kebijakan segera setelah penetapan undang-undang. Implementasi dipandang secara luas mempunyai makna pelaksanaan undang-undang dimana berbagai actor, organisasi, prosedur, dan teknik bekerja bersama-sama untuk menjalankan kewajiban dalam upaya untuk meraih tujuan-tujuan kebijakan atau program-program". (Budi Winarno, 2011: 147)

Van Meter dan Horn (1975) mendefinisikan "implementasi kebijakan sebagai, tindakantindakan yang dilakukan baik individu maupun kelompok-kelompok pemerintah atau swasta yang diarahkan pada tercapainya tujuan-tujuan yang telah digariskan dalam keputusan kebijakan. Implementasi kebijakan menyangkut tiga hal yaitu : 1. Adanya tujuan atau sasaran kebijakan. 2. Adanya aktifitas atau kegiatan pencapaian tujuan. 3. Adanya hasil kegiatan. Berdasarkan uraian tersebut dapat disimpulkan bahwa implementasi kebijakan merupakan suatu proses yang dinamis, dimana pelaksanaan kebijakan melakukan suatu aktifitas atau kegiatan, sehingga pada akhirnya akan mendapatkan hasil yang sesuai dengan tujuan dan sasaran kebijakan itu sendiri”. (Leo Agustini, 2008: 13).
Implementasi kebijakan dipengaruhi oleh dua variabel besar yaitu isi "kebijakan (content of policy) yang mencakup; (1) Sejauh mana kepentingan kelompok sasaran atau target groups termuat dalam isi kebijakan; (2) Jenis manfaat yang diterima oleh target group; (3) Sejauh mana perubahan yang diinginkan dari suatu kebijakan; (4) Apakah letak dari sebuah program sudah tepat; (5) Kebijakan telah menyebutkan implementornya dengan rinci; dan (6). Sebuah program di dukung oleh sumber daya manusia. Selanjutnya variabel lingkungan implementasi (contexts of policy), yang mencakup (1) seberapa besar kekuasaan, kepentingan, strategi yang dimiliki para aktor yang terlibat dalam implementasi kebijakan; (2) karakteristik institusi dan rejim yang sedang berkuasa, dan (3) tingkat kepatuhan dan responsivitas sasaran". (Suharsono, 2013)

Menurut Wibawa (1994) tahap implementasi kebijakan dapat dibedakan dengan tahap pembuatan kebijakan. Pembuatan kebijakan di satu sisi merupakan proses yang dimiliki logika bottom up dalam arti proses kebijakan diawali dengan penyampaian aspirasi, permintaan, atau dukungan dari masyarakat. Sedangkan implementasi kebijakan disisi lain di dalamnya memiliki logika top-down, dalam artian penurunan alternative kebijakan yang abstrak atau makro menjadi tindakan konkret atau mikro. (Deddy Mulyadi, 2015: 47)

George C. Edward III dalam Subarsono (2015) mengemukakan ada empat variabel yang mempengaruhi implementasi kebijakan yakni "komunikasi, sumberdaya, disposisi, dan struktur birokrasi. Keempat variabel tersebut saling berhubungan satu sama lain. (Subarsono, 2015).

\section{Komunikasi}

Keberhasilan implementasi kebijakan mensyaratkan agar implementor mengetahui apa yang harus dilakukan. Apa yang menjadi tujuan dan sasaran kebijakan harus ditransmisikan kepada kelompok sasaran (target group) sehingga akan mengurangi distorsi implementasi. Apabila tujuan dan sasaran suatu kebijakan tidak jelas atau bahkan tidak diketahui sama sekali oleh kelompok sasaran kemungkinan akan terjadi resistensi dari kelompok sasaran.

\section{Sumberdaya}

Tim implementor dan sumberdaya manusia juga berperan sebagai faktor penentu keberhasilan dari implementasi kebijakan publik. Sumberdaya tersebut dapat terwujud sumberdaya manusia, yakni kompetensi implementor, dan sumberdaya finansial. Apabila sumber daya manusia yang menjadi faktor utama penentu keberhasilan tidak mencakupi maka proses implementasi kebijakan tidak akan berjalan maksimal. Adanya tim implementor kebijakan publik merupakan salah satu bentuk dari sumberdaya yang memadai. 


\section{Disposisi}

Disposisi merupakan watak dan karakteristik yang dimiliki oleh implementor, seperti komitmen, kejujuran, sifat demokratis. Disposisi adalah salah satu penentu keberhasilan dari implementasi kebijakan. Apabila implementor memiliki disposisi yang baik maka dapat menjalankan kebijakan dengan baik seperti apa yang diinginkan oleh pembuat kebijakan. Dalam implementasi kebijakan banyak sekali yang tidak berhasil dalam implementasinya karena tim implementor tidak memiliki karakter disposisi yang baik. (Suharmo. 2013).

\section{Struktur Birokrasi}

Struktur organisasi yang bertugas mengimplementasikan kebijakan memiliki pengaruh yang signifikan terhadap implementasi kebijakan. Salah satu dari aspek struktur yang penting dari setiap organisasi adalah prosedur operasi yang standar (SOP). Dalam pengimplementasian kebijakan perlu dibuat SOP (Standar Operasional Procedure). SOP menjadi pedoman bagi setiap implementor dan bertindak. Agar proses implementasi lebih teratur dan terarah karena sudah ada tahap-tahapan dalam proses implementasi kebijakan". (Deddy Mulyadi, 2015: 68).

\section{B. Peraturan Menteri Kesehatan tentang Kejadian Luar Biasa (KLB)}

Menurut PERMENKES RI No. 1501 tahun 2010 Kejadian Luar Biasa (KLB) merupakan timbulnya atau meningkatnya kejadian kesakitan atau kematian yang bermakna secara epidemologi pada suatu daerah atau kurun waktu tertentu, dan merupakan keadaan yang dapat menjurus pada terjadinya wabah.

Penetapan Kejadian Luar Biasa (KLB) Menurut PERMENKES RI No. 1501 tahun 2010 suatu daerah dapat ditetapkan dalam keadaan Kejadian Luar Biasa (KLB) apabila memenuhi salah satu kriteria sebagai berikut:

1. "Timbulnya suatu penyakit menular tertentu yang sebelumnya tidak ada atau tidak dikenal pada suatu daerah:

2. Peningkatan kejadian kesakitan terus menerus selama tiga (3) kurun waktu dalam jam, hari atau minggu berturut-turut menurut jenis penyakitnya;

3. Peningkatan kejadian kesakitan dua kali atau lebih dibandingkan dengan periode sebelumnya dalam kurun waktu jam, hari atau minggu menurut jenis penyakitnya;

4. Jumlah penderita baru dalam periode waktu 1 (satu) bulan menunjukkan kenaikan dua kali atau lebih dibandingkan dengan angka rata-rata perbulan dalam tahun sebelumnya;

5. Rata-rata jumlah kejadian kesakitan perbulan selama 1 (satu) tahun menunjukkan kenaikan dua kali atau lebih dibandingkan dengan ratarata jumlah kejadian kesakitan perbulan pada tahun sebelumnya;

6. Angka kematian kasus suatu penyakit (Case Fatality Rate) dalam 1 (satu) kurun waktu tertentu menunjukkan kenaikan kenaikan 50\% (lima puluh persen) atau lebih dibandingkan dengan angka kematian kasus suatu penyakit periode sebelumnya dalam kurun waktu yang sama; dan

7. Angka proporsi penyakit (Proportional Rate) penderita baru pada satu periode menunjukkan kenaikan dua kali atau lebih disbanding satu periode sebelumnya dalam kurun waktu yang sama".

Menurut Permenkes Nomor 82 Tahun 2014 dalam hal "kejadian Penyakit Menular mengalami peningkatan yang mengarah pada KLB atau Wabah, Pemerintah, Pemerintah Daerah, dan masyarakat wajib melakukan kewaspadaan dan kesiapsiagaan serta Penanggulangan Penyakit Menular sesuai dengan ketentuan peraturan perundang-undangan. Dalam rangka penyelenggaraan Penanggulangan Penyakit Menular pada KLB atau Wabah, dibentuk Tim Gerak Cepat di tingkat pusat, provinsi, dan kabupaten/kota. Tim Gerak Cepat memiliki tugas dan fungsi:

1. Melakukan deteksi dini KLB atau Wabah;

2. Melakukan respon KLB atau Wabah; dan

3. Melaporkan dan membuat rekomendasi penanggulangan".

Untuk mengurangi dampak kesehatan, sosial, dan ekonomi akibat Penyakit Menular, Pemerintah dan Pemerintah Daerah melaksanakan mitigasi dampak melalui:

1. Penilaian status kesehatan masyarakat berdasarkan penyelidikan epidemiologis;

2. Memberikan jaminan kesehatan;

3. Menghilangkan diskriminasi dalam memberikan layanan dan dalam kehidupan bermasyarakat;

4. Menyelenggarakan program bantuan untuk meningkatkan pendapatan keluarga; dan,

5. Pemberdayaan masyarakat.

Adapun strategi yang dilakukan pemerintah menurut Permenkes Nomor 82 Tahun 2014 "untuk penyelenggaraan Penanggulangan Penyakit Menular meliputi:

1. Mengutamakan pemberdayaan masyarakat;

2. Mengembangkan jejaring kerja, koordinasi, dan kemitraan serta kerja sama lintas program, lintas sektor, dan internasional;

3. Meningkatkan penyediaan sumber daya dan pemanfaatan teknologi;

4. Mengembangkan sistem informasi; dan

5. Meningkatkan dukungan penelitian dan pengembangan". 
Sumber daya manusia dalam Permenkes nomor 82 tahun 2014 pasal 27 dalam "penyelenggaraan Penanggulangan Penyakit Menular meliputi tenaga kesehatan dan tenaga non kesehatan yang memiliki kompetensi yang sesuai dengan kegiatan penanggulangan. Kemampuan teknis sumber daya manusia diperoleh melalui pendidikan dan/atau pelatihan yang dibuktikan dengan sertifikat kompetensi sesuai dengan ketentuan peraturan perundang-undangan. Sedangkan sesuai dengan pasal 28 yaitu Pejabat Kesehatan Masyarakat yang mengelola program Penanggulangan Penyakit Menular harus memiliki kompetensi di bidang epidemiologi kesehatan, entomologi kesehatan, dan/atau kesehatan lingkungan. Pejabat Kesehatan Masyarakat harus mampu dalam perencanaan, pelaksanaan, pemantauan dan penilaian, bimbingan teknis dan rekomendasi tindak lanjut Penanggulangan Penyakit Menular. Dalam pasal 29 dijelaskan bahwa Pejabat Kesehatan Masyarakat pada satuan kerja Pemerintah dan Pemerintah Daerah dalam rangka menyelenggarakan program Penanggulangan Penyakit Menular memiliki tugas:

1. Melakukan penyelidikan epidemiologi terhadap tempat-tempat yang diduga sebagai sumber penyebaran penyakit;

2. Menetapkan status karantina dan isolasi;

3. Mengambil dan mengirim sampel dan/atau spesimen untuk keperluan konfirmasi laboratorium;

4. Memperoleh informasi dan data status kesehatan masyarakat dari fasilitas pelayanan kesehatan yang melakukan Penanggulangan Penyakit Menular; dan

5. Menyampaikan laporan dan rekomendasi tindak lanjut penanggulangan secara berjenjang".

Dalam hal penyakit menular muncul dengan gejala epidemi, petugas kesehatan masyarakat harus segera menyerahkan laporan mengenai kepekaan dan kesiapsiagaan pada tahap awal sesuai dengan persyaratan hukum. pemerintah dan pemangku kepentingan, baik di pusat, di provinsi, dan di kabupaten / kota. Koordinasi, jaringan, dan kemitraan bertujuan untuk:

1. Layanan advokasi;

2. Pencegahan, kontrol, dan pemberantasan penyakit menular;

3. Meningkatkan kapasitas sumber daya manusia, penelitian, penelitian dan kerjasama antar wilayah, luar negeri dan pihak ketiga;

4. Peningkatan komunikasi, informasi dan pendidikan; dan

5. Tingkatkan kapasitas kewaspadaan dini dan persiapan serta pencegahan epidemi.

\section{Dinas Kesehatan Kabupaten Ponorogo}

Dinas Kesehatan (Dinkes) daerah / wilayah

Kabupaten Ponorogo, Jawa Timur merupakan instansi yang bertanggungjawab mengenai kesehatan. Dinkes Kabupaten Ponorogo memiliki tugas untuk merumuskan kebijakan bidang kesehatan, melaksanakan kebijakan bidang kesehatan, melaksanakan evaluasi dan pelaporan bidang kesehatan, melaksanakan administrasi Dinas Kesehatan, dan melaksanakan fungsi lain yang terkait dengan urusan kesehatan. Selain fungsi-fungsi tersebut, melalui kantor dinas kesehatan ini juga pemerintah bertanggung jawab untuk melakukan penyuluhan kesehatan, penyuluhan hidup sehat dengan olahraga dan kesehatan jiwa bagi masyarakat serta keluarga. Dinas kesehatan ini juga bertugas sebagai penjamin dan pengawas fasilitas kesehatan di wilayah kerjanya, baik rumah sakit, alat kesehatan, obatobatan, dokter, klinik, apotek dan sebagainya. Kunjungi kantor dinas kesehatan terdekat ini untuk aduan atau informasi seperti info kesehatan, program kesehatan, hingga berita kebijakan kesehatan. (Profil Dinkes, 2017).

\section{METODE PENELITIAN}

\section{A. Definisi Operasional Dalam Penelitian}

Dalam penelitian ini, untuk memfasilitasi penelitian bagi para peneliti, diperlukan manajer operasional yang wajib menjelaskan semua indikator. Definisi operasional adalah elemen yang mengukur variabel atau memandu pelaksanaan studi. Variabel adalah konsep yang memiliki beragam nilai.

Definisi operasional adalah deskripsi karakteristik berdasarkan apa yang diamati adalah kunci dari definisi operasional. Karakteristik ini dapat dijelaskan dengan pengamatan dan pengukuran penelitian yang cermat berjudul "Implementasi Kebijakan Pemerintah Kabupaten Ponorogo tentang Penentuan Status Insiden Luar Biasa (KLB) Demam Berdarah Dengue" ( DBD), tahun 2019, di dinas kesehatan kabupaten Ponorogo ". Definisi operasional digunakan untuk memberikan ikhtisar pengukuran variabel pencarian menggunakan indikator berikut:

1. Penetapan kebijakan status Kejadian Luar Biasa

(KLB) di Kabupaten Ponorogo

a. Kriteria Kejadian Luar Biasa (KLB)

b. Kriteria pasien yang diklaim dalam Kejadian Luar Biasa (KLB)

2. Implementasi Kebijakan dapat di ukur dari indikator :
a. Keputusan Pemerintah Kabupaten Ponorogo/Dinas Kesehatan Kabupaten Ponorogo;
b. Tindakan yang dilakukan oleh Dinas Kesehatan Kabupaten Ponorogo;
c. Tujuan dan sasaran kebijakan Kejadian Luar Biasa (KLB);
d. Pelaku kebijakan;
e. Sasaran dan target kebijakan; dan 
f. Pelaksanaan Kebijakan. Dalam pelaksanaan kebijakan dapat diukur dari indikator :

i. Waktu pelaksanaan;

ii. Kendala dalam pelaksanaan.

\section{B. Model Penelitian}

\section{Jenis Penelitian}

Penelitian ini menggunakan penelitian kualitatif deskriptif. Deskriptif kualitatif adalah pengumpulan data dalam bentuk kata-kata, gambar dan bukan angka. Data dapat diperoleh dari skrip wawancara, catatan lapangan atau memo dan dokumen resmi lainnya. Dengan kompiler teoretis dari bawah ke atas, ini mewakili sejumlah besar data yang dikumpulkan dan saling berhubungan. (moleong, 2014).

\section{Lokasi Penelitian}

Lokasi penelitian merupakan obyek sekaligus tempat dimana peneliti melakukan penelitian guna untuk memperoleh data-data yang diperlukan. Adapun lokasi penelitian ini adalah di Dinas Kesehatan Kabupaten Ponorogo penelitian ini dilaksanakan berdasarkan penyesuaian dengan topik penelitian yaitu Implementasi Kebijakan Pemerintah Kabupaten Ponorogo Dalam Penetapan Status Kejadian Luar Biasa (KLB) Wabah Demam Berdarah Dengue (DBD) Tahun 2019 Di Dinas Kesehatan Kabupaten Ponorogo.

\section{Sumber Data Penelitian}

Dalam penelitian ini, para peneliti menggunakan wawancara mendalam, dokumentasi dan observasi lapangan untuk mengumpulkan data, yang kemudian diproses untuk menggambarkan bagaimana implementasi kebijakan Pemerintah Kabupaten Ponorogo untuk menentukan status Kejadian Luar Biasa (KLB) 2019 Demam Berdarah Dengue (DBD) di Unit Kesehatan Kabupaten Ponorogo.

Data primer adalah data tekstual dari wawancara dengan informan dalam bentuk rekaman video atau audio, dan catatan tertulis mungkin juga dalam bentuk foto. Data sekunder sudah merupakan data yang dapat diperoleh peneliti dengan membaca, melihat, dan mendengarkan (Sarwono, 2006). Sumber data diperoleh oleh peneliti melalui wawancara dan pengamatan langsung di lapangan, sedangkan data yang menguatkan diperoleh melalui dokumentasi dari sumber lain seperti artikel, koran, media sosial, dll., untuk mereproduksi data.

\section{Teknik Pengumpulan Data}

Teknik pengumpulan data dan informasi dari informan "menggunakan metode observasi, wawancara dan dokumentasi.

\section{a. Observasi}

Penelitian ini menggunakan metode observasi tidak langsung, dimana peneliti hanya mengamati kondisi lapangan tanpa terjun secara langsung.

\section{b. Wawancara}

Wawancara digunakan sebagai teknik pengumpulan data apabila peneliti ingin melakukan studi pendahuluan untuk menemukan permasalahan yang harus diteliti dan juga apabila peneliti ingin mengetahui hal-hal dari responden yang lebih mendalam dan jumlah respondennya sedikit/kecil. (Sugiyono, 2013). Wawancara merupakan penggalian informasi dengan melakukan Tanya jawab antara pewawancara atau interviewer dan yang memberi jawaban atau interview.

\section{c. Dokumentasi}

Dokumentasi merupakan pengumpulan data yang berupaya mengumpulkan data-data narasumber dari buku-buku, foto-foto yang berkaitan dengan obyek penelitian".

\section{Teknik Pemilihan Informan}

Dengan melakukan penelitian, peneliti menggunakan metode penelitian kualitatif untuk memperoleh data yang lebih spesifik. Penelitian kualitatif adalah metode penelitian di mana peneliti adalah instrumen kunci, mengambil sumber data. Hasil penelitian kualitatif lebih menekankan makna. (Sugiyono, 2013).

Teknik identifikasi informan yang digunakan dalam penelitian ini dilakukan dengan menggunakan teknik sampling beralasan. Reasoned sampling adalah metode yang digunakan oleh peneliti untuk menentukan informan. Untuk menentukan informan, peneliti tidak memilih secara acak, tetapi dengan sengaja memilih informan penelitian yang dapat memberikan informasi sejelas dan sedalam mungkin. (Sugiyono, 2013).

Ketika mengumpulkan data dan informasi dari informan yang dipilih oleh para peneliti untuk memberikan informasi terkait dengan judul penelitian, yaitu pelaksanaan kebijakan pemerintah kabupaten Ponorogo untuk menentukan status kejadian Luar Biasa (KLB) dari demam berdarah dengue (DBD), tahun 2019, di Unit Kesehatan Kabupaten Ponorogo. Informan dipilih dengan pertimbangan khusus dalam rangka memberikan informasi dan data tentang penentuan status wabah demam berdarah dengue (KFB) dari peristiwa luar biasa (KLB), sehingga mereka menjadi dianggap sebagai sumber daya penelitian. Oleh karena itu para peneliti mengidentifikasi informan sebagai berikut:

a. PJ pelaksana DBD

Sebagai penanggung jawab pelaksana program DBD

b. RSUD Dr. Harjono

RSUD yang menangani secara langsung bagaimana penanganan korban BDD

c. Pasien yang dirawat di RSUD Dr. Harjono. 


\section{Teknik Analisis Data Kualitatif}

Analisis data dalam penelitian kualitatif dilakukan ketika pengumpulan data dilakukan, setelah selesainya pengumpulan data dalam waktu tertentu. Pada saat wawancara, peneliti menganalisis tanggapan terhadap hasil wawancara jika, setelah analisis, peneliti tidak mendapatkan hasil maksimal, peneliti dapat mengambil kembali wawancara sampai dia mendapat hasil maksimal. Kegiatan analisis data kualitatif dilakukan secara interaktif. Kegiatan dalam analisis data meliputi 3: 1. reduksi data; 2. penyajian data; 3. Kesimpulan / verifikasi. (Miles dan Huberman dalam Sugiyono, 2013).

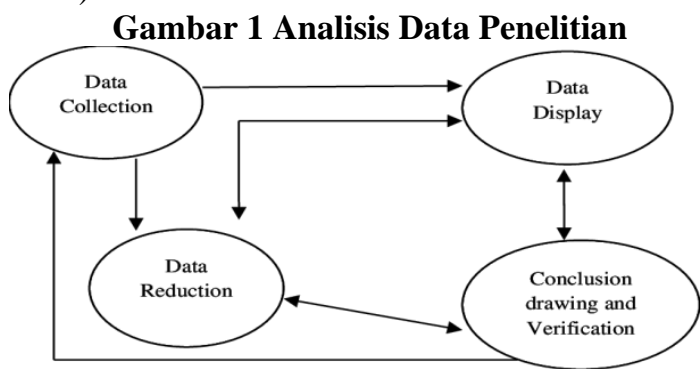

Sumber : Miles and Huberman's (1994) model of data analysis components Data reduction.

Tahapan proses analisis data menurut (Miles and Huberman's) dijelaskan sebagai berikut:

a. "Pertama, proses pengumpulan data. pada tahap ini peneliti melakukan proses pengumpulan data dengan menggunakan teknik pengumpulan data yang telah ditentukan sejak awal".

b. "Kedua, reduksi data. Reduksi data adalah sebagai proses pemilihan, pemusatan perhatian pada penyederhanaan, pengabstrakan, dan transformasi data yang muncul dari catatan tertulis di lapangan. Reduksi data berlangsung secara terus menerus sejalan dengan pelaksanaan penelitian".

c. Ketiga, "penyajian data. Penyajian data dimaknai sebagai sekumpulan informasi tersusun yang dapat memberi kemungkinan adanya penarikan kesimpulan dan pengambilan tindakan. Kegiatan reduksi dan penyajian data merupakan aktifitas yang terkait langsung dengan proses analisa data".

d. Keempat, "penarikan kesimpulan atau verifikasi. Tahap ini merupakan tahap akhir dari proses analisa data. Tahap ini dimaknai sebagai penarikan arti data yang telah ditampilkan. Beberapa cara yang dapat dilakukan dalam proses ini adalah dengan melakukan pencatatan untuk pola dan tema yang sama, pengelompokan, dan pencarian kasus".

\section{HASIL DAN PEMBAHASAN}

\section{A. Analisis Data}

1. Penetapan kebijakan status Kejadian Luar Biasa (KLB) di Kabupaten Ponorogo.

Dari hasil wawancara adapun kasus yang dijadikan KLB adalah dengan adanya peningkatan jumlah penderita yang signifikan setiap hari, minggu, bahkan perbulan yang meningkat dua kali lipat bahkan lebih itu dikatakan KLB. Dan di setiap kasus itu mempunyai kriteria yang berbeda-beda untuk menjadi KLB. Setiap Kabupaten pasti ada kasus yang seperti ini akan tetapi tidak semua bupati itu berani untuk menetapkan KLB dikarenakan banyaknya tanggung jawab yang harus dilakukan salah satunya adalah dengan mengratiskan biaya untuk pasien yang terkena DBD saat KLB.

Kebijakan yang telah ditetapkan oleh Bupati Ponorogo adalah mengratiskan semua pembiayaan selama KLB yang dirawat di Rumah Sakit maupun di Puskemas. Akan tetapi tidak semua pasien yang bisa diklaim dalam KLB DBD dengan ketentuan yang sudah ditetapkan oleh Bupati. Adapun Kriteria penetapan untuk pasien yang di klaim menjadi KLB DBD. Adapun syarat-syarat yang harus di penuhi antara lain persyaratan yang sesuai dengan SK bupati yang telah ditetapkan yaitu kriteria pasien DBD Rawat Inap (yang dibiayai pemerintah kabupaten Ponorogo dengan dana BTT) tahun anggaran 2019 harus memenuhi syarat yaitu diagnosa DBD, pasien rawat inap kelas III, Pasien merupakan penduduk Kabupaten Ponorogo, dan yang terakhir periode status pasien rawat inap pada tanggal 30 januari 2019 yang sesuai dengan SK Bupati Ponorogo. Selain itu ada juga persyaratan pasien yang di klaim per paket rawat inap itu juga ada ketentuan dari SK bupati yaitu surat pemintaan pembayaran, surat tagihan dari rumah sakit/puskesmas, kwitansi disertai nomor rekening rumah sakit/puskesmas, rekap pasien DBD rawat inap, KTP dan KK pasien penduduk Ponorogo, resume rawat inap, hasil laboratorium, billing (rincian rawat inap), persyaratan klaim dibuat rangkap 3.

\section{Implementasi kebijakan Kejadian Luar} Biasa (KLB)

Dari hasil wawancara dapat diketahui bahwa keputusan Pemerintah Kabupaten Ponorogo mengenai KLB DBD berdasarkan adanya kronologi kasus DBD yang jumlah pasien pada saat bulan januari hingga maret dengan total 1.621 penderita dan yang meninggal dunia sejumlah 10 orang maka banyaknya penderita dua kali lipat lebih dibandingkan tahun sebelumnya banyak pihak terkait seperti Rumah Sakit dan Puskesmas melaporkan mengenai tingginya pasien yang terkena DBD kepada Dinas Kesehatan Kabupaten Ponorogo. Kemudian Dinas Kesehatan melaporkan kejadian tersebut kepada pihak pemerintah 
Kabupaten Ponorogo. Untuk menindak lanjuti laporan dari Dinas Kesehatan terkait kasus tersebut Bupati menetapkan KLB DBD di Kabupaten Ponorogo. Maka keluarlah SK nomor 188.45/1070/405.10/2019 Keputusan Bupati Ponorogo tentang penetapan Kejadian Luar Biasa Demam Berdarah Dengue (KLB DBD) Kabupaten Ponorogo.

Tindakan yang dilakukan oleh Dinas Kesehatan Kabupaten Ponorogo untuk menanggulangi Kejadian Luar Biasa (KLB) DBD dengan meminta laporan harian dari pelayanan kesehatan terkait untuk kegiatan update harian mengenai data jumlah pasien yang terkena DBD, selanjutnya Dinas kesehatan melakukan gerakan serentak secara masif PSN yang dilakukan oleh petugas bersama lembaga pemerintah yang terkait seperti camat beserta staff nya, kepala desa, kader, dan warga masyarakat. Kegiatan PSN tidak hanya dilakukan oleh petugas kesehatan saja melainkan secara bersama-sama melakukan kegiatan PSN secara mandiri berupa menguras, mengubur dan menutup. Selain itu penanggulangan lain dilakukan dengan memberikan bubuk abate keseluruh RT, melakukan dan membentuk gerakan satu rumah satu jumantik, yang dimaksud jumantik yaitu setiap satu rumah harus ada yang bertanggung jawab untuk memantau ketidakadaan nyamuk dan kebersihan rumah. Selanjutnya Dinas Kesehatan melakukan kegiatan fooging masal ke seluruh desa yang ada penderita DBD. Selain itu Dinas terkait melakukan penyuluhan melalui siaran keliling, kegiatan yasinan dan kegiatan menanam serai di lingkungan sekitar rumah.

Tujuan dan sasaran dari kebijakan ini, tujuan Kejadian Luar Biasa (KLB) yaitu untuk menindak lanjuti banyaknya laporan dari pihak rumah sakit dan puskesmas yang ada di Kabupaten Ponorogo mengenai tingginya angka pasien yang terkena demam berdarah dengue hingga meningkat dua kali lipat yang terjadi di tahun ini tepatnya di bulan januari dibandingkan di tahun yang sebelumnya. Sasaran dari kebijakan yaitu seluruh masyarakat kabupaten Ponorogo yang terkena DBD pada waktu kejadian luar biasa KLB DBD di kabupaten Ponorogo.

Pelaku kebijakan KLB DBD yaitu dari pihak provinsi sampai ke masyarakat. Dari pihak provinsi bertanggung jawab dari segi pembiayaan karena kasus KLB ini bersifat gratis bagi masyarakat yang terkena DBD pada waktu KLB. Untuk pihak pemerintah kabupaten Ponorogo dan masyarakat terlibat langsung dalam pelaksanaan pengendalian KLB DBD.

Pelaksanaan kebijakan KLB DBD yaitu pada waktu ditetapkannya KLB tepatnya pada tanggal 3 januari 2019 sampai ditutupnya KLB yaitu pada tanggal 15 maret 2019. Sedangkan kendala dalam pelaksanaan kebijakan yang dihadapi oleh petugas dalam implementasi kebijakan ini adalah petugas pencegahan DBD ini sangat membutuhkan bantuan untuk pemberantasan sarang nyamuk dan masyarakat kurang peduli dengan adanya pencegahan yang dilakukan oleh petugas sehingga petugas kesulitan dalam pelaksanaan pemberantasan secara cepat. Peran dari pihak pemangku kebijakan pun juga kurang karena kegiatan ini tidak ada proses imbal baliknya atau pembiayaannya sehingga tidak disalahkan jika penderita DBD begitu cepat dalam proses penularan dan jumlah penderita pun meningkat drastis. Selain itu ada kendala yang dihadapi oleh Rumah Sakit yaitu ketentuan yang sudah ditetapkan oleh pemerintah kabupaten Ponorogo dengan ketentuan yang ada di Rumah Sakit itu bertimpangan karena ketentuan untuk pasien KLB yang ditentukan oleh pemerintah itu jika dilakukan di Rumah Sakit atau yang sesuai dengan medis itu akan membahayakan pasien karena penanganannya akan terlambat jadi akan membahayakan pasien.

\section{KESIMPULAN DAN SARAN}

\section{A. Kesimpulan}

Implementasi kebijakan penetapan status KLB DBD sudah terlaksana dengan baik hal ini terbukti dari hasil jawaban dari informan berdasarkan hasil penelitian di lihat dari indikator yaitu:

\section{Keputusan pemerintah tentang kejadian} luar biasa KLB DBD

Kronologi kasus DBD yang meletus dua kali lipat lebih dibandingkan tahun sebelumnya banyak pihak terkait seperti Rumah Sakit dan Puskesmas melaporkan mengenai tingginya pasien yang terkena DBD kepada Dinas Kesehatan Kabupaten Ponorogo. Kemudian Dinas Kesehatan melaporkan kejadian tersebut kepada pihak pemerintah Kabupaten Ponorogo. Untuk menindak lanjuti laporan dari Dinas Kesehatan terkait kasus tersebut Bupati menetapkan KLB DBD di Kabupaten Ponorogo. Maka keluarlah SK penetapan Kejadian Luar Biasa Demam Berdarah Dengue (KLB DBD) kabupaten Ponorogo.

2. Tindakan yang dilakukan pemerintah kabupaten Ponorogo untuk menanggulangi KLB DBD

Adapun tindakan yang dilakukan adalah untuk meminta laporan harian dari pelayanan kesehatan terkait untuk kegiatan update harian mengenai data jumlah pasien yang terkena DBD, selanjutnya Dinas kesehatan melakukan gerakan serentak secara masif PSN yang dilakukan oleh petugas bersama lembaga pemerintah yang terkait seperti camat beserta staff nya, kepala desa, kader, dan warga masyarakat. Kegiatan PSN tidak hanya dilakukan oleh petugas kesehatan saja melainkan secara bersama-sama melakukan kegiatan PSN secara mandiri berupa menguras, mengubur dan menutup. 


\section{Tujuan dan sasaran kebijakan KLB DBD}

Tujuan kebijakan ini adalah untuk menanggulangi dan memberantas penyakit yang sudah menyebar luas sehingga perlunya tindakan yang ekstra untuk pelaksanaannya. Adapun sasaran dari kebijakan ini yaitu seluruh masyarakat kabupaten Ponorogo yang terkena DBD pada waktu kejadian luar biasa KLB DBD di kabupaten Ponorogo.

\section{Pelaku dan pelaksanaan kebijakan KLB DBD}

Kebijakan ini hampir semua ikut terlibat dari provinsi hingga masyarakat ikut terlibat dalam hal pelaksanaan ini, karena kasus yang sangat membahayakan jadi perlu dilakukan tindak lanjut yang sangat ekstra dan partisipasi masyarakat pun sangat diperlukan untuk memberantas kejadian luar biasa (KLB) DBD. Pelaksanaan kebijakan KLB DBD yaitu pada waktu ditetapkannya KLB tepatnya pada tanggal 3 januari 2019 sampai ditutupnya KLB yaitu pada tanggal 15 maret 2019 .

\section{Kendala yang dihadapi dalam pelaksanaan}

\section{kebijakan KLB DBD}

Ketentuan yang sudah ditetapkan oleh pemerintah kabupaten Ponorogo dengan ketentuan yang ada di Rumah Sakit itu bertimpangan karena ketentuan untuk pasien KLB yang ditentukan oleh pemerintah itu jika dilakukan di Rumah Sakit atau yang sesuai dengan medis itu akan membahayakan pasien karena penanganannya akan terlambat jadi akan membahayakan pasien.

\section{B. Saran}

\section{Bagi Pemerintah Kabupaten Ponorogo}

Pemerintah kabupaten Ponorogo diharapkan untuk terus memantau dan memberi sosialisasi yang lebih terhadap masyarakat yang kurang akan pengetahuan, dan peran pemerintahan harus lebih peduli lagi akan kejadian ini.

\section{Bagi Masyarakat}

Masyarakat diharapkan untuk meningkatkan kepedulian nya terhadap kebersihan lingkungan. Supaya jika ada kasus yang serupa tentang penyakit menular tidak begitu banyak penderita yang terkena penyakit.

\section{Bagi RSUD Dr. Harjono}

RSUD diharapkan untuk memperbaiki pelayanan yang secara prosedur sehingga pasien yang di rawat inap bisa merasakan pelayanan yang maksimal.

\section{UCAPAN TERIMAKASIH}

Saya mengucapkan terima kasih kepada Kantor Dinas Kesehatan Ponorogo dan RSUD Dr. Harjono Ponorogo atas kegiatan penelitian ilmiah yang telah saya lakukan di instansi-instansi tersebut. Saya juga mengucapkan terima kasih kepada Dosen Pembimbing saya atas bimbingan yang telah diberikan, sehingga saya dapat menyelesaikan tugas akhir ini dengan baik.

\section{DAFTAR KEPUSTAKAAN}

Sudarsono, S. M. (2013). Kamus Hukum. Jakarta: PT RINEKA CIPTA.

Moleong, L. (2014). Metodologi Penelitian Kualitatif. Bandung: PT REMAJA ROSDAKARYA.

Novalia, R. F. (2016). Analisis Implementasi Peraturan Daerah Kota Semarang Nomor 5 Tahun $2010 \quad$ Tentang Pengendalian Penyakit Demam Berdarah Dengue (DBD) Di Puskesmas Kedungmungu.

Soehartono. (2011). Metode Penelitian Sosial. Bandung : Remaja Rosdakarya Offset.

Sugiyono. (2013). Metode Penelitian Pendidikan Pendekatan Kuantitatif Dan Kualitatif Dan $R \& D$. BANDUNG: Alfabeta.

Suharsono. (2011). Metode Penelitian Sosial. Bandung: Remaja Rosdakarya Offset.

Yusvita rahayu, i. s. (2017). Analisis Partisipasi Kader Jumantik Dalam Upaya Penanggulangan Demam Berdarah Dengue (DBD) Di Wilayah Kerja Puskesmas Indralaya. Jurnal Ilmu Kesehatan Masyarakat.

Massi, R. (2011). Implementasi Kebijakan Pengendalian Penyakit Demam Berdarah Dengue Di Pusat Kesehatan Talise Kota Palu, 1-13.

Rahayu, Y., \& Budi, I. S. (2017). Analisis Partisipasi Kader Jumantik Dalam Upaya Penanggulangan Demam Berdarah D Engue ( Dbd ) Di Wilayah Kerja Puskesmas Indralaya (November), 200-207.

Mulyadi,deddy. (2015) Study Kebijakan Publik Dalam Pelayanan Publik, Bandung : alfabeta.

Winarni Budi. (2011) Kebijakan Publik (Teori, Proses Dan Studi Kasus). Yogyakarta : Caps

Suharsono. 2013). Dasar-Dasar Kebijakan Publik: Kajian Proses Dan Analisis Kebijakan. Yogyakarta : Ombak (Anggota Ikapi)

Subarsono, A. (2015) analisis kebijakan publik konsep teori dan aplikasi. Yogyakarta: pustaka pelajar.

Suharmo. (2013). Dasar-Dasar Kebijakan Publik. Yogyakarta : Ombak

Perturan Menteri Kesehatan RI No. 1501 Tahun 2010 Tentang Kejadian Luar Biasa (KLB).

Peraturan Menteri Kesehatan No. 82 Tahun 2014 Tentang Kejadian Penyakit Menular.

Profil Rumah Sakit Umum Daerah Kabupaten Ponorogo Tahun (2017).

Profil Dinas Kesehatan Kabupaten Dinas Kesehatan Kabupaten Ponorogo (2016)

Sugiyono. (2010). Metode Penelitian Pendidikan 
(Pendekatan Kuantitatif, Kualitatif Dan $R \& D)$. Bandung. Alfabeta. 